\title{
Synthesis of Mesoporous Silica From Beach Sand Using Variation of Cetyl Trimethyl Ammonium Bromide (CTAB)
}

\author{
Lisna Efiyanti ${ }^{1, *}$ Wega Trisunaryanti ${ }^{2}$ Syaiful Bahri ${ }^{3}$ Yatim Lailun Ni'mah ${ }^{4}$
}

\author{
Nia Meisa Wulandari ${ }^{5}$ Satriyo D. Sumbogo ${ }^{2}$
}

\author{
${ }^{1}$ Forest Products Research and Development Center, The Ministry of Environment and Forestry, Bogor, 16610 , \\ Indonesia \\ ${ }^{2}$ Dept. of Chemistry, Faculty of Mathematics and Natural Science, Universitas Gadjah Mada, Yogyakarta, \\ 55281, Indonesia \\ ${ }^{3}$ Dept. of Chemical Engineering, Faculty of Engineering, University of Riau, Pekanbaru, Indonesia \\ ${ }^{4}$ Dept.of Chemistry, Faculty of Mathematics and Natural Science, Sepuluh November Institute of Technology, \\ Surabaya, 60111, Indonesia \\ ${ }^{5}$ Dept.t of Chemistry, Faculty of Science and Computer Science, Pertamina University, Teuku Nyak Arief, \\ Simprug, Kebayoran Lama, Jakarta 12220 \\ Corresponding author.Email: lisnaefiyanti@gmail.com
}

\begin{abstract}
The potential for sand in Indonesia is very abundant because Indonesia has a long coastline than other countries. This research was conducted to explore the potential of beach sand as an alternative raw material to replace commercial silica. To obtain the natural silica, the beach sand was prepared and extracted into mesoporous silica. The reflux method was chosen to extract silica using $\mathrm{NaOH}$ solution, $\mathrm{HCl}$ solution, and $\mathrm{CTAB}$ surfactant. The mesoporous structure was potentially affected by $\mathrm{CTAB}$ and $\mathrm{SiO}_{2}$ ratio, and therefore, this research was focused more on the effect of CTAB weight variation $(3 ; 4,5$ and $6 \mathrm{~g}$ ). Several instruments were used to analyze the characteristics of silica, such as Surface Area Analyzer (SAA), Scanning Electron Microscopy (SEM), and Fourier Transform Infrared Spectroscopy (FTIR). The mesoporous silica has siloxane (Si-O-Si) and silanol (Si$\mathrm{OH})$ functional group and showed a coral reef-like structure. The porosity properties of these materials ranging from $300-385 \mathrm{~m} 2 / \mathrm{g}$ for the specific surface area, 5-8.8 nanometer for pore diameter, and $0.4-0.8 \mathrm{~cm} 3 / \mathrm{g}$ for pore volume. Optimal CTAB weight found to be at $6 \mathrm{~g}$, which produces the mesoporous silica with a surface area of $385.928 \mathrm{~m} 2 / \mathrm{g}$, an average pore diameter of 6.015 nanometers, and pore volume of $0.579 \mathrm{~cm} 3 / \mathrm{g}$.
\end{abstract}

Keywords: beach sand, CTAB, mesoporous, silica

\section{INTRODUCTION}

Minerals that have developed, such as zeolite, generally have small pores so that the particles cannot run optimally, especially for particle sizes of more than $1.2 \mathrm{~nm}$. Porosity plays an important role in various reactions so that the concept of meso-size pore develops and becomes the center of attention today because it can be used for 2-50nm particles. Meso-sized porosity can be formed from silica or natural minerals and widely used for various purposes [1]. Meso-size pore material can be formed from mineral resources in nature because of its abundance so that it has the potential to become the raw material. One that developed is silica, it applied in various industries, especially in nanometer size with better quality. 
Previous research has revealed that mesopore silica can function as a catalyst [2], drug delivery $[3,4]$, and adsorbent [5]. This is because mesoporous silica has a large specific surface area with regular pores. So far, to obtain mesoporous silica, synthetic raw material sources such as tetraethyl orthosilicate (TEOS) are used [6]. However, some of the disadvantages of this raw material are that it is quite expensive and dangerous because it is flammable [7, 8]. Therefore we need an alternative raw material for silica that is non-toxic and safer for the environment, such as sourced from beach sand.

Beach sand contains quartz, therefore it is possible to be a source of silica because quartz is a crystalline form of silica [9]. Apart from quartz, beach sand contains other minerals such as $\mathrm{Fe}_{2} \mathrm{O}_{3}$, $\mathrm{K}_{2} \mathrm{O}, \mathrm{Al}_{2} \mathrm{O}_{3}, \mathrm{CaO}, \mathrm{P}_{2} \mathrm{O}_{5}, \mathrm{TiO}_{2}$, and so on with different amounts of content including quartz (silica) [10]. Indonesia is a country with the second-longest coastline in the world, owning more than $81.290 \mathrm{~km}$, of coastline [11] and granting Indonesia an abundance amount of sand. The Losari beach sand was known for having a high content of silica, which is $63.76 \%$ [12]. Some of the other beach sand research mentioned in previous research $[12,13,14]$.

In general, to obtain silica from sand, we use the acid-leaching process on sand with $\mathrm{HCl}$, the alkaline extraction method $(\mathrm{NaOH})$ to bind $\mathrm{SiO}_{2}$, and precipitation process carried out with acid. This acidbase route has been successful in producing amorphous mesoporous structures [15]. In mesoporous materials forming, surfactant micelles are used as a template. The resulting pore properties can be obtained from changes in micelle structure and morphology, for example by variations in the type of surfactant, molecular structure, concentration, and addiction [16]. The surfactant commonly used in forming mesoporous is cetyltrimethylammoniumBromide (CTAB), a cationic surfactant 2 .

\section{MATERIALS AND METHODS}

\subsection{Materials}

The materials that were used are Parangtritis Beach Sand, CTAB (Himedia), HCl (Merck), aquades, and $\mathrm{NaOH}$ (Merck). The tools that were used in this research are digital scales (OHAUS), chemical glassware, a $\mathrm{pH}$ indicator (Merck), a centrifuge, stirrer, furnace, spatula, thermometer, oven (Memmert). The instruments for characterization are a Surface Area Analyzer $\mathrm{N}_{2}$ (JWGB-Meso 112) FTIR (Thermo Scientific).

\subsection{Methods}

\subsubsection{Silica Extraction from Beach Sand}

The sand was collected from Parangtritis Beach. The sand sample was washed and dried overnight at a temperature of $100^{\circ} \mathrm{C}$. Afterward, the cleaned sand sieved into 100 mesh in size and weighted $100 \mathrm{~g}$ to be refluxed and stirred with $500 \mathrm{~mL}$ of $\mathrm{HCl}$ solution at a temperature of $80^{\circ} \mathrm{C}$ for 3 hours. The sample was centrifuged and the solid residue was collected. The residue washed until its freed from $\mathrm{HCl}$ then dried overnight at temperature of $100^{\circ} \mathrm{C}$. The dried sample was then refluxed and stirred $\mathrm{NaOH}$ solution $(500$ $\mathrm{mL}$ ) for 2 hours. The solid residue and filtrate were separated using a centrifuge, the filtrate was then collected for further steps.

\subsubsection{The Silica synthesis}

The CTAB solutions made into three variations by dissolving 3, 4.5, and $6 \mathrm{~g}$ of CTAB with $50 \mathrm{~mL}$ distilled water. Each of the CTAB solutions added into $100 \mathrm{~mL}$ filtrate from previous steps, and then this mixture was added with $3 \mathrm{M}$ HCL solution until the $\mathrm{pH}$ value reach 7 [17]. The solution was heated at a temperature of $60^{\circ} \mathrm{C}$ for 4 hours, aged for $66 \mathrm{~h}$ to add condensation time, then filtered, washed, and dried at a temperature of $100^{\circ} \mathrm{C}$ for 2 hours. The cleaned silica was calcined at $550^{\circ} \mathrm{C}$ for six hours to obtain mesoporous silica.

\subsubsection{Characterization of Mesoporous Silica}

The functional group that presents in mesoporous silica was analyzed using FTIR. The pore characteristics, such as the specific surface area, pore volume and pore diameter, were analyzed and calculated using the Gas Adsorption Analyzer. For morphological characteristics, it is obtained from SEM analysis

\section{RESULTS AND DISCUSSION}

The synthesis process of mesoporous silica from beach sand was done using surfactant variation. The surfactant used in this research was CTAB, a cationic quaternary surfactant with a long alkane chain that can produce a large pore diameter. In meso-size pore formation, the CTAB has an advantage in a shorter time of synthesis, compared to non-ionic surfactant [18]. The synthesis of mesopore silica was started by mixing CTAB and sodium silicate and then added with dropwise of $1 \mathrm{M} \mathrm{HCl}$. The $\mathrm{HCl}$ was the chosen acid because of the easiness of removing its side 
product, $\mathrm{NaCl}$, which is soluble and easily removed from the system (eq.1). To ensure that $\mathrm{NaCl}$ was completely removed, the filtrate was added with the $\mathrm{AgNO}_{3}$ solution to form white $\mathrm{AgCl}$ precipitate if there is any chlorine in the filtrate (eq. 2).

$\mathrm{Na}_{2} \mathrm{SiO}_{3}$ (aq) $+2 \mathrm{HCl}_{\text {(aq) }} \rightarrow \mathrm{SiO}_{2}$ (s) $+2 \mathrm{NaCl}_{(\text {aq) }}+\mathrm{H}_{2} \mathrm{O}_{\text {(aq) }}$ (1) $\mathrm{Ag}^{+}+\mathrm{Cl}^{-} \rightarrow \mathrm{AgCl}(2)$

When the synthesis process is carried out, stirring will facilitate the hydrolysis process and the sodium silicate will be condensed in a more stable mesostructure and a high degree of order. Then, continued aging for 24 hours to increase the condensation time to prevent shrinkage of the meso-structure during the calcination stage [19]. Calcination is performed to remove CTAB to form mesoporous silica. From this process, we can obtain the yield of mesoporous silica (table 1)

Table 1. The yield of mesoporous silica with CTAB variaton

\begin{tabular}{llll}
\hline No & Sample & $\begin{array}{l}\text { Yield of } \\
\text { silica with } \\
\text { template } \\
\text { before } \\
\text { calcination } \\
(\%)\end{array}$ & $\begin{array}{l}\text { Yield of } \\
\text { mesoporous } \\
\text { silica with } \\
\text { template after } \\
\text { calcination } \\
(\%)\end{array}$ \\
\hline 1. & SMP (3) & 2.521 & 1.67 \\
\hline 2. & SMP (4.5) & 2.405 & 1.546 \\
\hline 3. & SMP (6) & 2.345 & 1.478 \\
\hline
\end{tabular}

From the table 1, it can be seen that the yield of mesoporous silica from sand is small but bigger than Meyori's (2018) research [12], which obtained a maximum yield of xerogel silica of $0.8 \%$. The sand components are probably one of the factors affected the low yield. There are many other minerals besides silica which have a high composition, such as $\mathrm{Fe}_{2} \mathrm{O}_{3}$. Then, the acid leaching preparation process is also allegedly affecting the yield, because if the acid leaching does not work perfectly, other minerals will not separate and interfere with the synthesis of mesoporous silica. In the washing process after acid leaching, and after giving $\mathrm{NaOH}$, it will reduce the weight of silica, as well as in the calcination process, and it is also necessary to pay attention to the concentration and time of silica deposition after $\mathrm{HCl}$ drops.

\subsection{Functional Group Analysis Using FTIR}

Determination of the functional group in the material (beach sand as a raw material (PP), beach sand after acid leaching (PPAc), CTAB, silica with template but without calcination (SCP), and mesoporous silica after calcination (SMP) ) was done using FTIR, as shown in Figure 1. There is a significant difference in spectral patterns between raw material, SCP and SMP. The spectral patterns of the beach sand before and after the acid leach is not significantly different, so the possibility of the process did not affect the initial structure of the sand much. The CTAB showed to have $\mathrm{CH}_{3}$, methylene $\mathrm{CH}_{2}, \mathrm{C}-\mathrm{H}$ in alkyl chain, and C-N group at $2923 \mathrm{~cm}^{-}$ 1, $2850 \mathrm{~cm}^{-1}, 1477 \mathrm{~cm}^{-1}$ and $964 \mathrm{~cm}^{-1}$ [20,21], respectively. Those functional groups were matched with the CTAB structure in Figure 1.


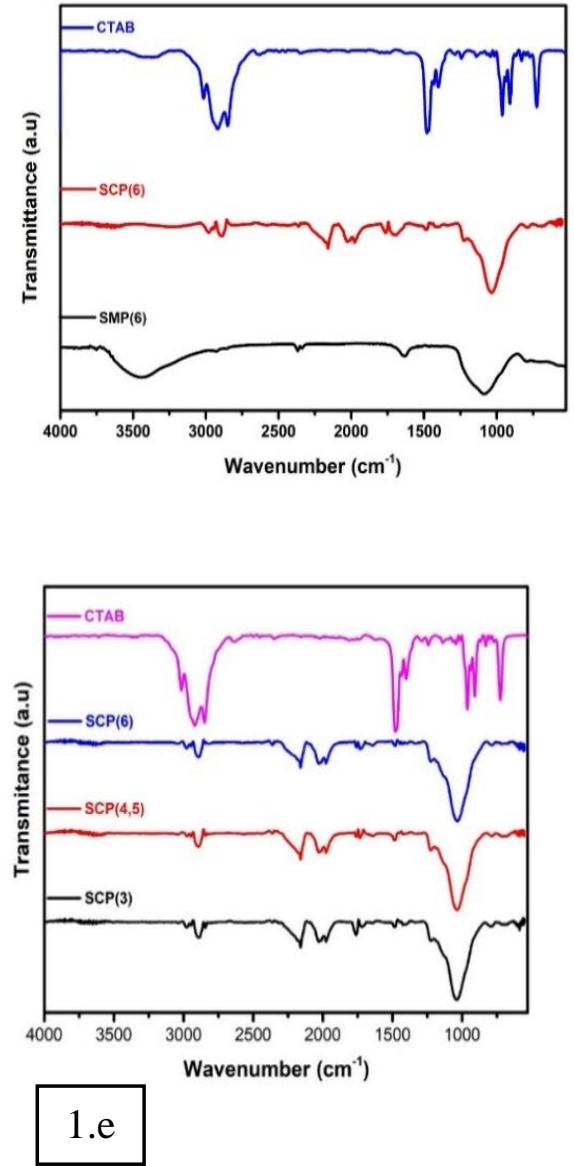

Figure 1. FTIR spectra of PP, PPAc, and SMP 6 (1.a); SCP $3 \mathrm{~g}$ of CTAB, SCP $4.5 \mathrm{~g}$ of CTAB, SCP 6 $\mathrm{g}$ of CTAB (1b), SMP3, SMP4.5, SMP6 (1.c); CTAB, SCP6, SMP6 (1.d), and CTAB, SCP3, SCP $4,5, \operatorname{SCP} 6(1 . \mathrm{e})$

The set of SCP (SCP3, SCP4.5, and SCP6) showed few CTAB distinctive features, $2882 \mathrm{~cm}^{-1}$ and $2883 \mathrm{~cm}^{-1}$, which indicates that some of the CTAB still attached on the materials. The CTAB absorption bands disappear in SMP, indicates that the calcination process successfully remove the $\mathrm{CTAB}(22)$. The SMP set showed new absorption bands, i.e., hydroxyl (O-H), siloxane (Si-O-Si) symmetric and asymmetric, silanol (Si-OH), Si-O bending, and Si-OH at $3448 \mathrm{~cm}^{-1}, 1087 \mathrm{~cm}^{-1}, 470 \mathrm{~cm}^{-}$ , and $794 \mathrm{~cm}^{-1}$, respectively $[23,24,25,26]$. The silica functional groups that present in SMP indicates that the majority of the silica structure remain intact [22].

\subsection{Morphology Characterization Using SEM}

Identification of the SMP morphology obtained from SEM analysis and references, shown in Figure 2. In general, the silica morphology has coral reeflike structures, with heterogeneous size due to impurities in sample size $[7,27]$. The calculation of particle size was difficult due to the aggregation on each sample, but qualitatively, the particle size usually was inversely proportional to the weight of the $\mathrm{CTAB}$ used. The formation of the micelle and the enhancement of the bond between CTAB and silica probably cause the phenomenon. The silica surface tends to be heterogeneous, where the particles are hardly seen and appeared to be agglomerated grain [13], with the size under 100 nanometer [28].
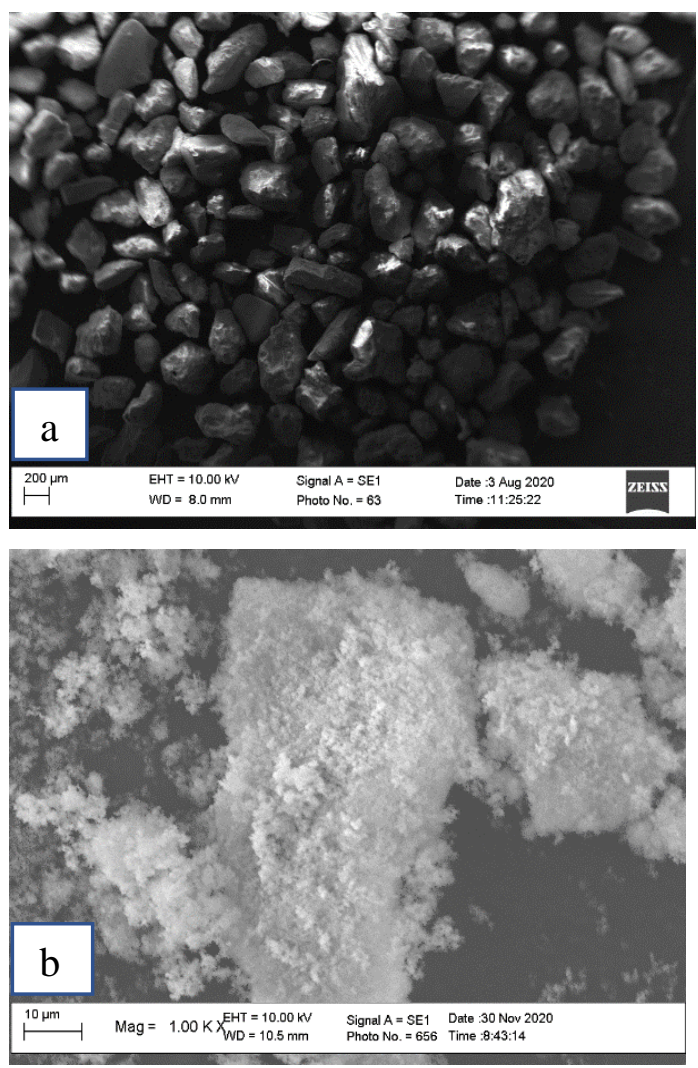

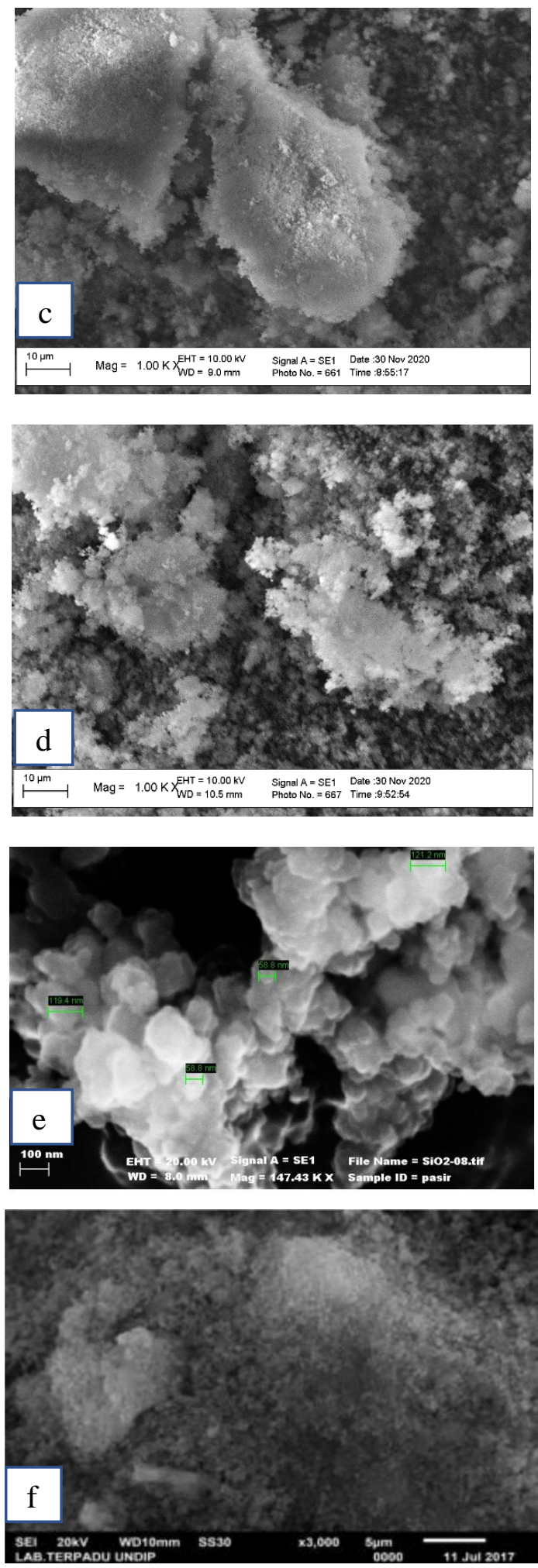

Figure 2. SEM images of the Parangtritis beach sand as a raw material (a), mesoporous silica with $3 \mathrm{~g}$ of CTAB (b), $4.5 \mathrm{~g}$ of CTAB (c), $6 \mathrm{~g}$ of CTAB (d), silica of the Bancar sand beach (e)[29] and silica xerogel from the Panjang-Bengkulu sand beach (f) [12]

\subsection{Adsorption-Desorption Analysis of Sample}

The nitrogen adsorption-desorption method was done to analyze the sample pore characteristics. Figure 3 shows an adsorption-desorption pattern of all SMP catalysts have a similar trend, both from the sharpness of the curve in the relative pressure area of 0.2-0.4 and the curve pattern formed during the adsorption and desorption processes. The curve sharpness indicates mesoporous uniformity, where a sharper curve gives a more uniform pore size [18].

The porosity properties of the SMP could be seen in Table 1. All the SMP synthesized from beach sand under the variation of the weight of the CTAB template could be classified as mesoporous materials. The surface area of the SMP was an increase as the effect of a higher dose of CTAB. This phenomenon could occur because of

CTAB's role in the system, directing the mesoporous formation so the agglomeration process less possible to take place.
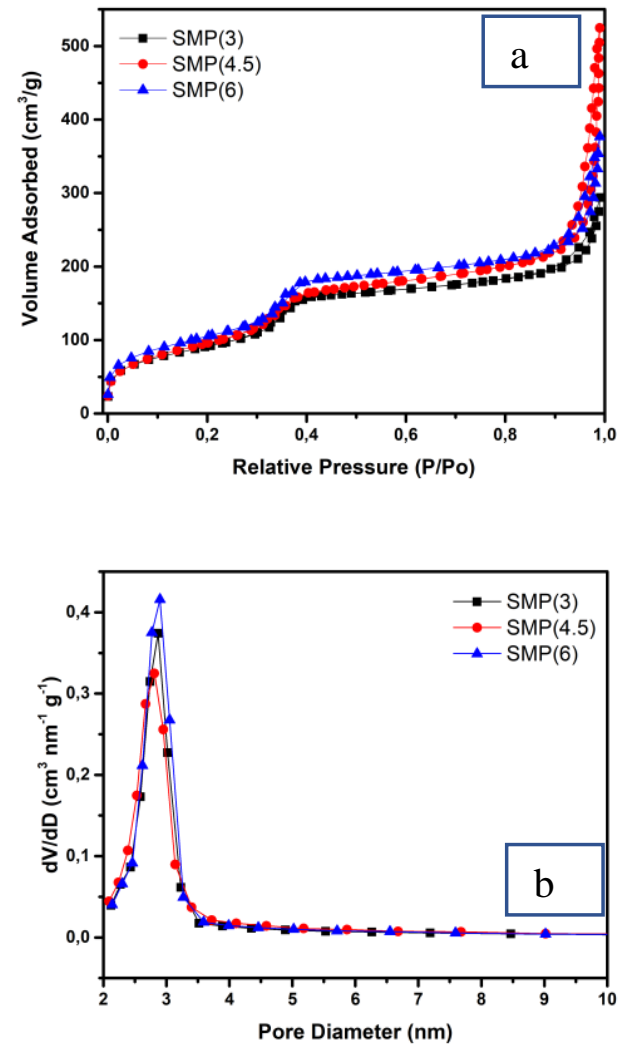

Figure 3. The adsorption-desorption of $\mathrm{N}_{2}$ isotherm curve (a) and pore size distribution of SMP (b) 
Table 2. The properties of mesoporous silica

\begin{tabular}{lccc}
\hline Sample & Surface Area $\left(\mathbf{m}^{2} / \mathbf{g r a m}\right)$ & $\begin{array}{c}\text { Average Pore Diameter } \\
(\text { nanometer })\end{array}$ & $\begin{array}{c}\text { Total Pore Volume } \\
\left(\mathbf{c m}^{\mathbf{3}} / \mathbf{g r a m}\right)\end{array}$ \\
\hline SMP (3) & Mesoporous silica from Parangtritis beach sand \\
SMP (4.5) & 338.209 & 5.243 & 0.443 \\
SMP (6) & 362.928 & 8.881 & 0.806 \\
\hline
\end{tabular}

The highest surface area and an average pore diameter are $385.928 \mathrm{~m}^{2} / \mathrm{g}$ and $6.015 \mathrm{~nm}$ for mesoporous silica with $6 \mathrm{gr}$ CTAB template. These results indicate that mesoporous character from beach sand was higher than Lapindo mud (the surface area of $75.105 \mathrm{~m}^{2} / \mathrm{g}$; a pore volume of $0.1974 \mathrm{~cm}^{3} / \mathrm{g}$ and an average pore diameter of 105.14 A) [30] also silica from natural diatomite (the surface area of $38-250 \mathrm{~m} 2 / \mathrm{g}$; pore volume of $0.071-0.364 \mathrm{~cm} 3 / \mathrm{g}$ and average pore diameter of 5-8 nanometer) [31].

\section{CONCLUSION}

Mesoporous Silica from beach sand can be synthesized with CTAB template. The mesoporous silica has a surface area spesific $(300-385 \mathrm{~m} 2 / \mathrm{g})$; an average pore diameter ranging from $5-8.8 \mathrm{~nm}$; and a pore volume ranging from $0.4-0.8 \mathrm{~cm} 3 / \mathrm{g}$. The functional groups of silica were $\mathrm{Si}-\mathrm{OH}$ and $\mathrm{Si}-\mathrm{O}-\mathrm{Si}$. The CTAB optimum weight based on the highest surface area in this research was found to be at $6 \mathrm{~g}$.

\section{ACKNOWLEDGMENT}

The authors highly acknowledge and thank to the Ministry of Research and Tecnology (KEMENRISTEK/BRIN), Indonesia for providing support and facilities, through KRUPT 2021 scheme (Kolaborasi Riset Unggulan Perguruan Tinggi) with contract number 198/SP2H/LT/DRPM/2021.

\section{REFERENCES}

[1] Barrabino, Synthesis of mesoporous silica particles with control of both pore diameter and particle size, Master of Science Thesis in Materials and Nanotechnology program, Department of Chemical and Biological Technology Division of Applied Surface Chemistry, Chalmers University Of Technology, 2011.

[2] C. Watthanachai, S. Ngamcharussrivichai, Pengprecha, Synthesis and characterization of bimodal mesoporous silica derived from rice husk ash, Engineering Journal 23(1) (2019) 2534. DOI: https://doi.org/10.4186/ej.2019.23.1.25

[3] N.I. Vazquez, Z. Gonzalez, B. Ferrari, Y. Castro, Synthesis of mesoporous silica nanoparticles by sol-gel as nanocontainer for future drug delivery applications, Boletin de la Sociedad Espanola de Ceramica y Vidrio 56 (3) (2017) 139-145. DOI: http://dx.doi.org/10.1016/j.bsecv.2017.03.002

[4] P. Zhao, MC. Liu, HC. Lin, XY. Sun, YY. Li, SQ. Yan, Synthesis and drug delivery applications for mesoporous silica nanoparticles, Journal Med. Biotechnology 1(1) (2017) 1-5.

[5] S. Kachbouri, N. Mnasri, E. Elaloui, Y. Moussaoui, Tuning particle morphology of mesoporous silica nanoparticles for adsorption of dyes from aqueous solution, Journal Saudi Chemical Society, 22 (4) (2018) 405-415. DOI: https://doi.org/10.1016/j.jscs.2017.08.005

[6] S. Ghosh, V. Vandana, Nano-structured mesoporous silica/silver composite: Synthesis, characterization and targeted application towards water purification, Material Research Bulletin 88 (2017) 291-300. DOI: https://doi.org/10.1016/j.materresbull.2016.12.04 $\underline{4}$

[7] H. Purwaningsih, Y. Ervianto, V.M. Pratiwi, D. Susanti, A. Purniawan, Effect of Cetyl Trimethyl Ammonium Bromide as Template of Mesoporous Silica MCM-41 from Rice Husk by Sol-Gel Method,in Proceeding IOP Conference Series, Material Science and Engineering 515(1) (2019). DOI: https://doi.org/10.1088/1757$\underline{899 X / 515 / 1 / 012051}$

[8] Merck, "Tetraethyl Orthosilicate" (Online), Available:

https://www.sigmaaldrich.com/catalog/product/al drich/86578?lang=en\&region=ID, Accessed: August $15^{\text {th }} 2020$.

[9] J. Castro, What is sand ? (Online), 2013, Available: https://www.livescience.com/34748what-is-sand-beach-sand.html, Accesed: August $16^{\text {th }} 2020$. 
[10] Alimin, Maryono, S.E. Putri, Analisis Kandungan Mineral Pasir Pantai Losari Kota Makassar Menggunakan XRF dan XRD, Jurnal

[11] Chemica 17(2) (2016) 19-23. [In Bahasa Indonesia]

[12] Kementerian Energi dan Sumber Daya Mineral Kapal Survei Geomarin III sebagai Sebuah Jawaban (Online), 2017, Available: https://www.esdm.go.id/en/media-center/newsarchives/kapal-survei-geomarin-iii-sebagaisebuah-jawaban, Accessed: March 2020. [In Bahasa Indonesia]

[13] F. Meyori, R. Elvia, IN. Candra, Sintesis dan karakterisasi xerogel hasil kopresipitasi dari pasir Pantai Panjang Bengkulu, ALOTROP, Jurnal Pendidikan dan Ilmu Kimia 2(1) (2018) 46-51. [In Bahasa Indonesia]

[14] S. Hadi, Munasir, Triwikantoro, Sintesis silika berbasis pasir alam Bancar menggunakan metode kopresipitasi, Jurnal fisika dan aplikasinya 7(2) (2011) 1-4. DOI: https://dx.doi.org/10.12962/j24604682.v7i2.902. [In Bahasa Indonesia]

[15] F. Madina, R. Elvia, IN. Candra, Analisis kapasitas adsorpsi silika dari pasir pantai panjang bengkulu terhadap pewarna rhodamine $b$, ALOTROP, Jurnal Pendidikan dan Ilmu Kimia 1(2) (2017) 98-101. [In Bahasa Indonesia]

[16] A. Mourhly, M. Khachani, A. El Hamidi, M. Kacimi, M. Halim, S. Arsalane, The synthesis and characterization of low-cost mesoporous silica $\mathrm{SiO}_{2}$ from local pumice rock, Nanomaterials and Nanotechnology, 5(35) (2015) 1-7. DOI: https://doi.org/10.5772\%2F62033

[17] K.W. Park, J.Y. Kim, H.J. Seo, O.Y. Kwon, Preparation of Mesoporous Silica by Nonionic Surfactant Micelle-Templated Gelation of $\mathrm{Na}_{2} \mathrm{SiO}_{3}$ and $\mathrm{H}_{2} \mathrm{SiF}_{6}$ and Application as a Catalyst Carrier for the Partial Oxidation, Scientific Reports Natureresearch 9(1) (2019) 18. DOI: https://doi.org/10.1038/s41598-01950053-y

[18] J.F. Fatriansyah, F.W. Situmorang, D. Dhaneswara, Ekstraksi silika dari sekam padi: metode refluks dengan naoh dan pengendapan menggunakan asam kuat $(\mathrm{HCl})$ dan asam lemah $\left(\mathrm{CH}_{3} \mathrm{COOH}\right)$, in: Prosiding Seminar Nasional Fisika ke-3 Universitas Riau, Pekanbaru, 2018, pp. 123-127. [In Bahasa Indonesia]
[19] Zhao, Y. Wan, W, Zhou. Ordered Mesoporous Materials, Wiley-VCH Verlas \& Co, KGaA, 2013.

[20] TW. Kim, PW. Chung, VSY. Lin, Facile synthesis of monodisperse spherical MCM-48 mesoporous silica nanoparticles with controlled particle size, Chemistry of Materials, 22(17) (2010) 5093-5104. DOI: https://doi.org/10.1021/cm1017344

[21] U. Nithiyanantham, S.R. Ede, M.F. Ozaydin, H. Liang, A. Rathishkumar, S. Kundu, Low temperature, shape-selective formation of $\mathrm{Sb}_{2} \mathrm{Te}_{3}$ nanomaterials and their thermoelectric applications, Royal Society of Chemistry Advance 5(109) (2015) 89621-89634. DOI: https://doi.org/10.1039/C5RA17284E

[22] JA. Ramos Guivar, E.A. Sanches, CJ. Magon, EG Ramos-Fernandes, Preparation and characterization of cetyltrimethylammonium bromide (CTAB)-stabilized $\mathrm{Fe}_{3} \mathrm{O}_{4}$ nanoparticles for electrochemistry detection of citric acid, Journal of Electroanaytical Chemistry 755 (2015) $158-166$.

DOI: http://dx.doi.org/10.1016/j.jelechem.2015.07.036

[23] G. Yang, Y. Deng, H. Ding, Z. Lin, Y. Shao, Y. Wang, A facile approach to synthesize MCM-41 mesoporous materials from iron ore tailing: Influence of the synthesis conditions on the structural properties. Applied Clay Science 111 (2015) 61-66. DOI: http://dx.doi.org/10.1016/j.clay.2015.04.005

[24] S. Suyanta, A. Kuncaka, Utilization of Rice Husk As Raw Material in Synthesis of Mesoporous Silicates Mcm-41, Indonesian Journal of Chemistry 1(3) (2011) 279-284. DOI: https://doi.org/10.22146/ijc.21393

[25] Majchrzak-Kucęba, W. Nowak, Characterization of MCM-41 mesoporous materials derived from polish fly ashes, International Journal of Mineral Processing 101 (2011) 100-111 DOI: http://dx.doi.org/10.1016/j.minpro.2011.09.002

[26] T.E. Purbaningtias, P. Kurniawan, B. Wiyantoko, D. Prasetyoko, Suprapto, Pengaruh penambahan surfaktan pada modifikasi material alam, Akta Kimia Indonesia. 4(2) (2019) 118-132. [In Bahasa Indonesia]

[27] S.C. Precelia, R.R.D.J.N. Subagyono, C. Saleh, Sintesis silika mesopori tersulfonasi dari abu daun bambu petung (Dendrocalamus asper), 
Jurnal Atomik 03(1) (2018) 61-67. [In Bahasa Indonesia]

[28] S. Arunmetha, A. Karthik, SR. Sither, M. Vinoth, R. Suriyaphraba, P. Manivasakan, V. Rajendran, Size-dependent physicochemical of mesoporous nanosilica produced from natural quartz sand using three different methods, Royal Society Cemistry Advances (5) (2015) 47390-47397. DOI: http://dx.doi.org/10.1039/C5RA07074K

[29] R. Hayati, Astuti, Sintesis nanopartikel silika dari pasir pantai purus Padang-Sumatera Barat dengan metode kopresipitasi, Jurnal Fisika Unand 4(3) (2015) 282-287. [In Bahasa Indonesia]

[30] Munasir, Triwikantoro, M. Zainuri, Darminto, Ekstraksi dan sintesis nanosilika berbasis pasir bancar dengan metode basah, Jurnal Penelitian Fisika dan Aplikasinya 3(2) (2013) 12-17. [In Bahasa Indonesia]

[31] W. Trisunaryanti, II. Falah, MF. Marsuki, Synthesis of Mesoporous Silica-Alumina from Lapindo Mud Using Gelatin from Catfish Bone as a Template: Effect of Extracting Temperature on Yield and Characteristic of Gelatin as well as Mesoporous Silica-Alumina, in: 15th International Conference on Environmental Science and Technology Rhodes, Greece, 2017

[32] RMM. Aboelenin, NA. Fathya, HK. Faragb, MA. Sheriefb, Preparation, characterization and catalytic performance of mesoporous silicates derived from natural diatomite: Comparative studies, Journal of Water Process Engineering 19 (2017) 112-119. DOI: http://dx.doi.org/10.1016/j.jwpe.2017.07.017 